\title{
Demographic Data of Cystic Fibrosis Patients in a Tertiary Care Center in Saudi Arabia
}

Banjar $\mathrm{H}^{1^{*}}$, Kadan $\mathrm{H}^{2}$, Al-Abdaly $\mathrm{D}^{3}$, Sheikh $\mathrm{M}^{3}$, Al-Kaf $\mathrm{S}^{3}$, Ghomraoui $\mathrm{R}^{4}$, AIDoss A ${ }^{3}$, Al-Eid $\mathrm{M}^{3}$

\author{
${ }^{1}$ Department of Pediatrics, King Faisal Specialist Hospital \& Research Centre (KFSHRC), Riyadh, Saudi Arabia \\ ${ }^{2}$ College of Medicine, Al-Faisal University, Riyadh, Saudi Arabia \\ ${ }^{3}$ Biostatistics, Epidemiology, and Scientific Computing Department, King Faisal Specialist Hospital \& Research Centre \\ (KFSHRC), Riyadh, Saudi Arabia \\ ${ }^{4}$ Elm University for Dentistry and Pharmacy, Riyadh, Saudi Arabia
}

Corresponding Author: Hanaa Banjar, MD, FRCPC ${ }^{\text {ORCID ID }}$

Address: Professor of Pediatrics, Al-Faisal University, Consultant Pediatric Pulmonology, Department of Pediatrics, (KFSHRC). P.O.Box. 3354, MBC-58, Riyadh 11211, Saudi Arabia; Tel: +9661-442-7761; Fax No: +966-1-442-7784, +966503493022; E-mail: hanaa@kfshrc.edu.sa

Received date: 28 May 2020; Accepted date: 19 June 2020; Published date: 27 June 2020

Citation: Banjar H, Kadan H, Al-Abdaly D, Sheikh M, Al-Kaf S, Ghomraoui R, AIDoss A, Al-Eid M. Demographic Data of Cystic Fibrosis Patients in a Tertiary Care Center in Saudi Arabia. Asp J Pediatrics Child Health. 2020 June 27;2(2):44-51.

Copyright (C) 2020 Banjar H, Kadan H, Al-Abdaly D, Sheikh M, Al-Kaf S, Ghomraoui R, AIDoss A, Al-Eid M. This is an open-access article distributed under the Creative Commons Attribution License, which permits unrestricted use, distribution, and reproduction in any medium provided the original work is properly cited.

\begin{abstract}
Introduction: Cystic Fibrosis has been reported before in almost all Arab countries with an incidence ranges from 1:2500- 1:7000. Presentations varied, but mainly due to recurrent chest infection and Pancreatic Insufficiency. Median survival has been far below North American countries. Delayed diagnosis and delayed management account for the low median survival.

Objectives: To present the demographic data of Cystic Fibrosis patients and their families, that involves their social status and education.

Methodology: A retrospective chart review as part of the Cystic Fibrosis registry data from the period January 1998 to December 2018. All confirmed CF patients of all age groups who contributed their demographic information were included and analyzed.

Results: A total of 430 confirmed Cystic Fibrosis patients. 236 (96\%) patients survived, and 10 (4\%) died. Two hundred and thirteen (49.5\%) were males, and 217 (50.5\%) were females. Eighty-three percent consanguinity rate. Forty-five had a family history of Cystic Fibrosis, and the diagnosis was suggested by family history in $9.5 \%$ of patients. 415 (98.1\%) were of Saudi nationality. 156 (36.5\%) were from the Eastern province. The mean age at diagnosis was 3.46 years $(S D \pm 5.547)$. Median survival around 22 years. Mean Sweat chloride was $92.04 \mathrm{mmol} / \mathrm{L}$ (17.343). In reviewing the educational level of 247 patients, the level of elementary school accounted for 90 $(36.1 \%)$ of patients, $24(9.7 \%)$ of mothers, and $21(8.5 \%)$ of fathers. Similarly, $43(17.4 \%) / 22(8.9 \%) / 102$ $(41.3 \%)$ were in the preparatory level, $35(14.3 \%) / 43(17.4 \%) / 51(20.6 \%)$ were in the high school level, and 23 $(9.3 \%) / 39(15.8 \%) / 46$ (18.6\%) were in the college level, respectively. Regarding the employment: 145 (58.7\%) patients are students, $3(1.2 \%)$ are part-time employees, and 15 (6.0\%) are full time employees. 207 (83.8\%) mothers are housewives, $2(0.8 \%)$ are students, and $29(11.7 \%)$ have full-time employment. Paternal
\end{abstract}


Citation: Banjar H, Kadan H, Al-Abdaly D, Sheikh M, Al-Kaf S, Ghomraoui R, AIDoss A, Al-Eid M. Demographic Data of Cystic Fibrosis Patients in a Tertiary Care Center in Saudi Arabia. Asp J Pediatrics Child Health. 2020 June 27;2(2):44-51.

employment showed that $210(85.0 \%)$ are full time, and 7 (2.8\%) are part-time employees. Regarding their accommodation: 77 (31.2\%) of Cystic Fibrosis parents owned a villa, 81 (32.8\%) rented an apartment, and 79 (32\%) owned their own apartment.

Conclusion: More than $2 / 3$ of $\mathrm{CF}$ patients are students at the elementary school level, and only $6.0 \%$ have a fulltime job, which makes them completely dependent on both parents for their care. Median survival improved from 8 years in 1984 to 22 years. Further efforts need to be applied to different aspects of care to further improve median survival.

\section{Keywords}

Cystic fibrosis, Epidemiology, Education, Socioeconomic Status, Consanguinity, Survival, Arabs

\section{Introduction}

Cystic fibrosis (CF) is an autosomal recessive disorder caused by a mutation in the gene encoding a protein which functions as a chloride channel [1]. The chloride channel, cystic fibrosis transmembrane conductance regulator (CFTR) exists in the apical membrane of exocrine epithelial cells in the body. In the last 75 years, the survival of $\mathrm{CF}$ patients has risen dramatically from a few months to the average age of 45 years [1]. The rise in life expectancy is due to several reasons: improved medical treatment, treating patients in specialized CF centers, early diagnosis, respiratory physiotherapy, and liver or lung transplantation [1].

\section{Demographics, Incidence/Prevalence, Survival:}

The prevalence of CF in Arab countries is estimated to range from 1:2,56o to 1:1500o [1,2] (Table-1), likely owing to ethnicity and the degree of consanguinity which is estimated at approximately $65 \%$ [3]. In the UAE, the prevalence of CF was estimated to be 1 in 15,876 [4]. The incidence rate of CF is 1 in 2500 live births in Jordan and 1 in 5000 live births in Bahrain [57]. The median survival in Arab countries is low, estimated at 10-20 years of age [1,2] (Table-1). In 2004, a study of 27 European (EU) countries showed that the mean prevalence of CF was 0.737 per 10,000 [8] and a mean age of 45-50 years [9-12].

In a cross-sectional study, disease severity was inversely correlated with socioeconomic factors such as median household income by zip code and state insurance coverage. Patients with low socioeconomic status (SES), however, were treated more aggressively by healthcare providers who likely recognize those patients' likelihood of worse disease outcomes. A 2011 study found that individuals of higher SES were more likely to die above the median survival age [13]. Children of higher socioeconomic groups, living in upscale areas or with well-educated mothers, were more likely to be better informed on their disease and receive better healthcare at clinics [14]. Oates et al. found that maternal college education, annual income $>$ \$50,0oo, and more adults in the household were independently correlated with better treatment adherence [15]. Socioeconomically disadvantaged patients had limited access to specialist care centers in the UK [13]. A literature review of demographics and the effect of social and economic status on the survival of CF populations from different countries around the world showed that it is of variable effect (Table-1) [14,16-23].

\section{Objectives}

To present the demographic data of CF patients and their families, which involves their social status and education.

\section{Methodology}

Retrospective Chart Review of all CF patients referred to $\mathrm{CF}$ clinic during the period from January 1998 to December 2018. Data on demographic, laboratory, educational, Employment, and social status levels of all CF patients and their parents were presented.

\section{Definitions:}

A patient with $\mathrm{CF}$ disease is defined as:

1. One who has typical pulmonary manifestations and/or typical gastrointestinal manifestations (GI) and/or a history of cystic fibrosis in the 
Citation: Banjar H, Kadan H, Al-Abdaly D, Sheikh M, Al-Kaf S, Ghomraoui R, AIDoss A, Al-Eid M. Demographic Data of Cystic Fibrosis Patients in a Tertiary Care Center in Saudi Arabia. Asp J Pediatrics Child Health. 2020 June 27;2(2):44-51.

\section{Original Article}

immediate family in addition to sweat chloride concentration $>60 \mathrm{mmol} /$ liter.

2. Pathologic CFTR mutations on both alleles.

3. One who has typical pulmonary and manifestations and borderline or normal sweat chloride (CL) level (30-6o mmol/L) and or pathologic CFTR mutations on both alleles.

\begin{tabular}{|c|c|c|}
\hline \multicolumn{3}{|r|}{ Table-1: Literature Review of Demographic Data of Cystic Fibrosis Worldwide } \\
\hline Ref & $\begin{array}{l}\text { Country or } \\
\text { Region }\end{array}$ & Study Design, Results, \& Comments \\
\hline $\mathbf{1}$ & Middle East & $\begin{array}{l}\text { Systematic Review, } 1: 2500 \text { live births in Jordan, } 1: 5000 \text { live births in Bahrain, Median survival age } \\
\text { at 10-20 years, consanguinity- } 50 \% \text { in general, } 85 \% \text { in CF families }\end{array}$ \\
\hline 4 & $\begin{array}{l}\text { United Arab } \\
\text { Emirates }\end{array}$ & Pilot study to determine prevalence; $400 \mathrm{UAE}$ nationals, $26 \mathrm{CF}$ patients, $\mathrm{P}=1: 15,876$ \\
\hline 5 & Asia & $\begin{array}{l}\text { CF epidemiology between } 1960 \text { and 2015, I=1:350,00o live births in Japan; 1:9200 Asian } \\
\text { immigrants in Canada, 1:10,000 in the UK, 1:40,000 in the US }\end{array}$ \\
\hline 8 & $\begin{array}{l}\text { Europe }(27 \\
\text { countries) }\end{array}$ & $\mathrm{P}=0.737: 10,000.35,806 \mathrm{CF}$ patients in a total population of $486,114,000$ \\
\hline 9 & International & $\begin{array}{l}53 \text { national CF registries between } 2008 \text { and 2011, In non-EU countries, lower median age and } \\
\text { poor survival rates }\end{array}$ \\
\hline 10 & $\begin{array}{l}\text { Europe }(35 \\
\text { countries) }\end{array}$ & $\begin{array}{l}\text { CF demographics and CFTR genotype data, In non-EU countries, higher infant mortality, More } \\
\text { common in males }\end{array}$ \\
\hline 11 & $\begin{array}{l}\text { European } \\
\text { Union }\end{array}$ & $\begin{array}{l}\text { Cross-sectional study using data gathered for } 29,025 \text { patients, Median age in EU countries (17 } \\
\text { years) older than in non-EU countries ( } 12 \text { years); Patients older than } 40 \text { years were } 5 \% \text { in EU and } \\
2 \% \text { in non-EU countries. }\end{array}$ \\
\hline 12 & International & Literature Review, Median survival 25 years for $\mathrm{F}$ and 30 years for $\mathrm{M}$ \\
\hline 16 & $\begin{array}{l}\text { England and } \\
\text { Wales }\end{array}$ & $\begin{array}{l}\text { Cross-sectional study of annual deaths related to CF from } 1959 \text { to } 2008 \text {, Median age at death } \\
\text { higher in M more F, (25-29 yrs for M, 20-24 for F), Low SES is associated with greater disease } \\
\text { morbidity and mortality in CF. }\end{array}$ \\
\hline 16 & Australia & $\begin{array}{l}\text { Cross-sectional Analysis, } 2986 \text { CF patients } 48 \% \text { F. median age at death was } 27.9 \text { for } \mathrm{M} \text { and } 25.3 \\
\text { for F }\end{array}$ \\
\hline 17 & USA & $\begin{array}{l}\text { Cross-sectional study of 22,714 CF patients, } 1: 2986 \text { births. } 6.65 \% \text { Hispanic ( } 1511 \mathrm{CF} \text { patients), } \\
\text { Early diagnosis=prevalent among Hispanic patients. }\end{array}$ \\
\hline 14 & USA & Historical Cohort 1986 to 1994, Disease severity correlated with SES. \\
\hline 18 & Canada & 1993 to 2002 of 1,174 participants, Higher income = better PFT \\
\hline 19 & USA & $\begin{array}{l}\text { Retrospective cohort of } 23,817 \mathrm{CF}, 44 \% \text { increased risk for death for low-income groups } \\
(<\$ 20,000) \text { compared to high-income groups }(>\$ 50,000)\end{array}$ \\
\hline 15 & USA & $\begin{array}{l}\text { Literature Review, Maternal college education, annual income }>\$ 50,000 \text {, were independently } \\
\text { correlated with better treatment adherence }\end{array}$ \\
\hline 20 & USA & $\begin{array}{l}\text { a cohort of } 1375 \text { CF patients, } 24.8 \% \text { exposed to maternal smoking after birth, more prevalent in } \\
\text { low SES families, Maternal education at high school or less in } 28.1 \% .26 .8 \% \text { have an annual } \\
\text { household income of }<\$ 40,000.43 .8 \% \text { without insurance or Medicaid, Low SES and smoke } \\
\text { exposure had independent adverse effects on PFT and nutritional outcomes. }\end{array}$ \\
\hline 21 & USA & $\begin{array}{l}\text { 12,822 patients diagnosed } 1986 \text { and 2000, Early diagnosis by neonatal screening leads to lower } \\
\text { prevalence of RTIs }\end{array}$ \\
\hline 22 & USA & $\begin{array}{l}\text { Cross-sectional on 4,571 patients and 1,826 parents, Worse emotional and social functioning } \\
\text { among African-American and Hispanic patients correlated with clinical outcomes. }\end{array}$ \\
\hline 23 & Germany & $\begin{array}{l}\text { Case-control study, Quality of Life reported to be worse among CF women. Depression increased } \\
\text { as lung function declined. }\end{array}$ \\
\hline
\end{tabular}

Ref $=$ References, $\mathrm{P}=$ Prevalence, $\mathrm{I}$ = Incidence, $\mathrm{RTI}=$ Respiratory tract infection, $\mathrm{SES}=$ Socioeconomic status, $\mathrm{M}=\mathrm{Males}, \mathrm{F}$ $=$ Females, EU $=$ European, $\mathrm{PFT}=$ Pulmonary function test, $\mathrm{USA}=$ United States of America 
Citation: Banjar H, Kadan H, Al-Abdaly D, Sheikh M, Al-Kaf S, Ghomraoui R, AIDoss A, Al-Eid M. Demographic Data of Cystic Fibrosis Patients in a Tertiary Care Center in Saudi Arabia. Asp J Pediatrics Child Health. 2020 June 27;2(2):44-51.

\section{Original Article}

Ethical considerations and Statistical Method:

After obtaining the ethical approval by the research advisory committee (or institutional review board, IRB). The Declaration of Helsinki and good clinical practice guidelines were followed. Data collection and data entry were supervised by the principal investigator. All data needed were obtained by retrospective chart review and were stored in a pediatrics research unit, accessed only by the principle investigator and the assigned Clinical Research Coordinator. The entire patient's information kept strictly confidential. Each patient was given a study number, and all patients' data were entered into the designated data sheet (EXCEL) without any patient's identification. The department of Biostatistics Epidemiology and Scientific Computing (BESC) carried out statistical analysis of the data. The frequency of events was obtained by mean (SD), with simple descriptive analysis.

\section{Results}

A total of 430 confirmed CF patients. 236 (96\%) patients survived, and 10 (4\%) died. 213 (49.5\%) were males, and $217(50.5 \%)$ were females. $83 \%$ consanguinity rate. $45 \%$ had a family history of $\mathrm{CF}$, and the diagnosis was suggested by family history in $9.5 \%$ of patients. $415(98.1 \%)$ were of Saudi nationality. $156(36.5 \%)$ were from the Eastern province. The mean age at diagnosis was 3.46 years (5.5) which is improved compared to a previous study in 1998 ( $3.46 \pm 5.5$ years VS $33 \pm 40$ months), which could be explained due to the increasing CF diagnosis during adult age groups (26-28). Mean Sweat chloride was $92.04 \mathrm{mmol} / \mathrm{L}$ (17.343). In reviewing the educational level of 247 patients, the level of elementary school accounted for 90 (36.1\%) of patients, $24(9.7 \%)$ of mothers, and $21(8.5 \%)$ of fathers (Table-2). Similarly, 43 (17.3\%)/ 22 (8.9\%)/ $102(41.3 \%)$ were in the preparatory level, $35(14.1 \%) /$ $43(17.4 \%) / 51(20.6 \%)$ were in the high school level, and $23(9.2 \%) / 39(15.8 \%) / 46(18.6 \%)$ were in the college level, respectively (Table-2). Regarding the employment: $145(58.7 \%)$ patients are students, 3 $(1.2 \%)$ are part-time employees, and $15(6.0 \%)$ are full time employees. 207 (83.8\%) mothers are housewives, $2(0.8 \%)$ are students, and $29(11.7 \%)$ have full time employment (Table-3). Paternal employment showed that $210(85.0 \%)$ are full time, and $7(2.8 \%)$ are parttime employees (Table-3). Regarding their accommodation: $77(31.2 \%)$ of CF parents owned a villa, 81 (32.8\%) rented an apartment, and 79 (32\%) owned their own apartment (Table-4). The median survival around 22 years compared to 8 years in 1984 (Fig-1).

\begin{tabular}{|c|c|c|c|c|c|c|}
\hline \multicolumn{7}{|c|}{ Table-2: Educational Level [Total 247 Patients] } \\
\hline \multirow{2}{*}{ Variable } & \multicolumn{2}{|c|}{ Patients } & \multicolumn{2}{|c|}{ Mothers } & \multicolumn{2}{|c|}{ Fathers } \\
\hline & Number & Percent & Number & Percent & Number & Percent \\
\hline Elementary & 90 & 36.4 & 24 & $9 \cdot 7$ & 21 & 8.5 \\
\hline Preparatory & 43 & $17 \cdot 4$ & 22 & 8.9 & 102 & $41 \cdot 3$ \\
\hline High School & 35 & $14 \cdot 3$ & 43 & $17 \cdot 4$ & 51 & 20.6 \\
\hline College/Higher & 23 & $9 \cdot 3$ & 39 & 15.8 & 46 & 18.6 \\
\hline Illiterate & 11 & $4 \cdot 4$ & 22 & 8.9 & 26 & 10.5 \\
\hline Unknown & 45 & 18.2 & 97 & $39 \cdot 3$ & 1 & 0.4 \\
\hline Total & 247 & 100 & 247 & 100 & 247 & 100 \\
\hline
\end{tabular}


Citation: Banjar H, Kadan H, Al-Abdaly D, Sheikh M, Al-Kaf S, Ghomraoui R, AIDoss A, Al-Eid M. Demographic Data of Cystic Fibrosis Patients in a Tertiary Care Center in Saudi Arabia. Asp J Pediatrics Child Health. 2020 June 27;2(2):44-51.

\section{Original Article}

\begin{tabular}{|l|c|c|c|c|c|c|}
\hline \multicolumn{7}{|c|}{ Table-3: Employment Status [Total 247 Patients] } \\
\hline \multirow{2}{*}{ Variable } & \multicolumn{2}{|c|}{ Patients } & \multicolumn{2}{c|}{ Mothers } & \multicolumn{2}{c|}{ Fathers } \\
\cline { 2 - 8 } & Number & Percent & Number & Percent & Number & Percent \\
\hline Full Time & 15 & 6 & 29 & 11.7 & 210 & 85 \\
\hline Part Time & 3 & 1.2 & 0 & 0 & 7 & 2.8 \\
\hline Student & 145 & 58.7 & 2 & 0.8 & 0 & 0 \\
\hline Unemployed & 47 & 19 & 4 & 1.6 & 23 & 9.3 \\
\hline Housewife & 1 & 0.4 & 207 & 83.8 & - & 2.8 \\
\hline Unknown & 36 & 14.7 & 5 & 2 & 7 & 100 \\
\hline \multicolumn{1}{|c|}{ Total } & 247 & 100 & 247 & 100 & 247 & 2.8 \\
\hline
\end{tabular}

\begin{tabular}{|c|c|c|c|}
\hline \multicolumn{4}{|c|}{ Table-4: Demographic Data [Total=430 patients] } \\
\hline \multicolumn{2}{|c|}{ Demographic } & Number & Percent \\
\hline \multirow{2}{*}{$\begin{array}{c}\text { Gender } \\
\text { Total }=430\end{array}$} & Male & 213 & 49.5 \\
\hline & Female & 217 & 50.5 \\
\hline \multirow{2}{*}{$\begin{array}{l}\text { Nationality } \\
\text { Total }=423\end{array}$} & Saudi & 415 & 98.1 \\
\hline & Non-Saudi & 8 & 1.9 \\
\hline \multirow{3}{*}{$\begin{array}{c}\text { Race } \\
\text { Total }=425\end{array}$} & White & 2 & 0.5 \\
\hline & Arabian & 422 & $99 \cdot 3$ \\
\hline & Asian & 1 & 0.2 \\
\hline \multirow{2}{*}{$\begin{array}{l}\text { Country of Origin } \\
\text { Total }=428\end{array}$} & KSA & 421 & 98.4 \\
\hline & Other & 7 & 1.6 \\
\hline \multirow{5}{*}{$\begin{array}{l}\text { Region of KSA } \\
\text { Total }=427\end{array}$} & East & 156 & 36.5 \\
\hline & West & 77 & 18 \\
\hline & Central & 100 & 23.4 \\
\hline & North & 52 & 12.2 \\
\hline & South & 42 & 9.8 \\
\hline \multirow{5}{*}{$\begin{array}{l}\text { Accommodation Type } \\
\text { Total }=247\end{array}$} & Owned Apartment & 79 & 32 \\
\hline & Owned Villa & 77 & 31.2 \\
\hline & Rental Apartment & 81 & 32.8 \\
\hline & Rental Villa & 7 & 2.8 \\
\hline & Other & 3 & 1.2 \\
\hline \multirow{3}{*}{$\begin{array}{l}\text { Consanguinity } \\
\text { Total }=242\end{array}$} & First Cousin & 109 & 45 \\
\hline & Any Relation & 92 & 38 \\
\hline & Unrelated & 41 & 16.9 \\
\hline \multirow{2}{*}{$\begin{array}{c}\text { Family History of CF } \\
\text { Total }=238\end{array}$} & Yes & 107 & 45 \\
\hline & No & 131 & 55 \\
\hline \multirow{2}{*}{$\begin{array}{c}\text { Dx Suggested by FHx } \\
\text { Total }=430\end{array}$} & No & 389 & 90.5 \\
\hline & Yes & 41 & 9.5 \\
\hline
\end{tabular}


Citation: Banjar H, Kadan H, Al-Abdaly D, Sheikh M, Al-Kaf S, Ghomraoui R, AIDoss A, Al-Eid M. Demographic Data of Cystic Fibrosis Patients in a Tertiary Care Center in Saudi Arabia. Asp J Pediatrics Child Health. 2020 June 27;2(2):44-51.

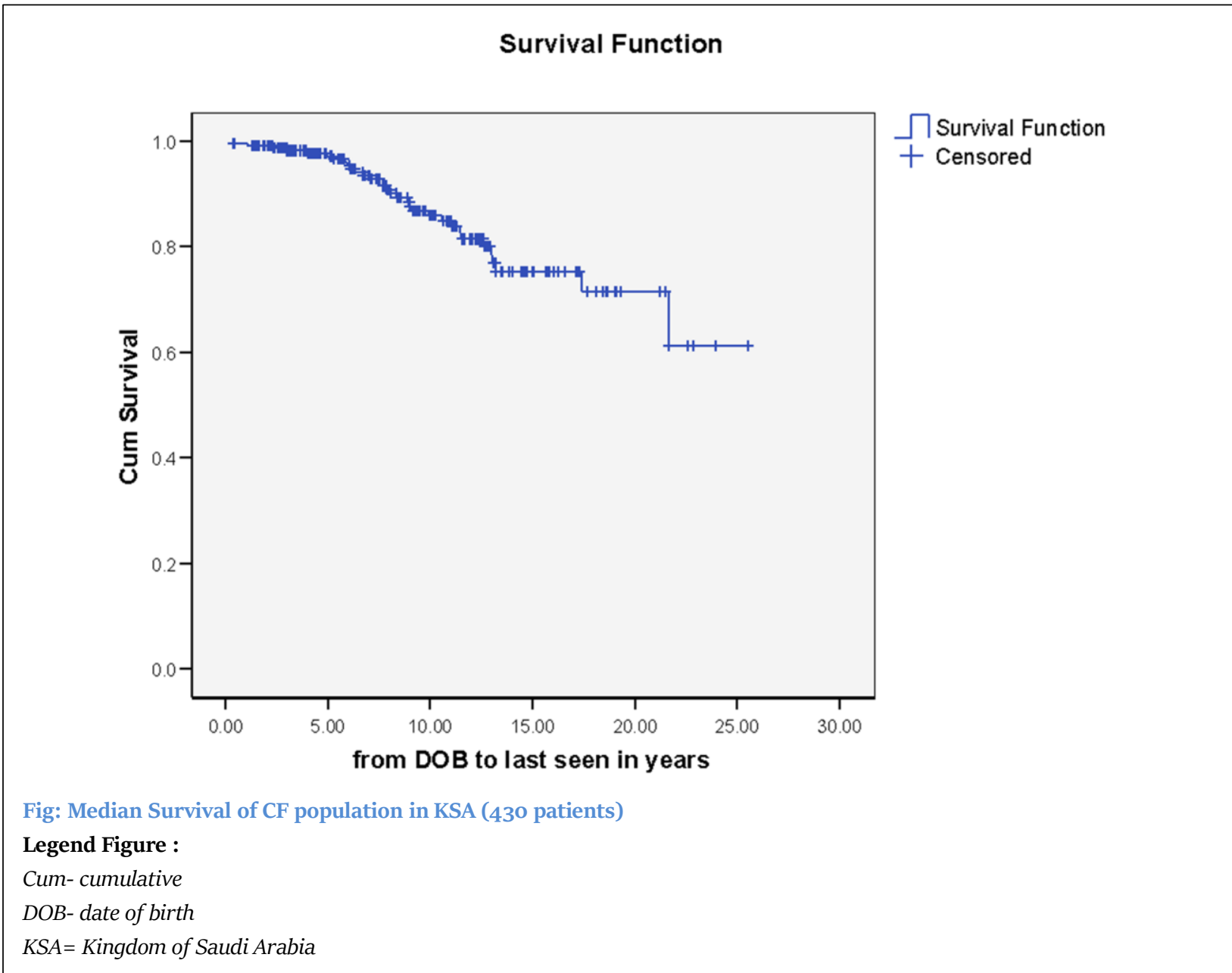

\section{Discussion}

Our findings showed consistently similar results in all demographic data as the previous report from our center with a smaller CF population [24] as the following: more females have CF than males; however, the difference was not significant. The majority of patients are Arabian, predominantly Saudi citizens residing in the Eastern province $[25,26]$. The mean age at $\mathrm{CF}$ diagnosis has increased compared to a previous study in 1998 ( $3.46 \pm 5.5$ years VS $33 \pm 40$ months), which could be explained due to the increasing $\mathrm{CF}$ diagnosis during adult age groups [25-26]. The median survival of 22 years is markedly improved compared to 8 years in 1984 as per our registry data (Fig-1) $[1,25,26]$. This finding indicates the improvement in medical care and the awareness improvement of physicians and medical staff.

The majority of patients are at the elementary school which leaves the patients almost entirely dependent on both parents for their care and fully dependent on their fathers alone for financial support. The majority of patients have the security of owning their accommodation; however, it can also call to question the relevance of conditions of their accommodation - location, climate, hygiene, etc. which would require a further inquiry to better understand patients' lifestyles.

Further efforts need to be applied to different aspects of care to improve survival to match other European or North American countries of 45-50 years $[1,27,28]$. Factors that need to be improved include Early diagnosis and referral to experienced centers, compliance of taking medications, chest physiotherapy, early Nutritional rehabilitation, and proper genetic counseling [1].

\section{Conclusion}

More than $2 / 3$ of $\mathrm{CF}$ patients are students at the 
Citation: Banjar H, Kadan H, Al-Abdaly D, Sheikh M, Al-Kaf S, Ghomraoui R, AIDoss A, Al-Eid M. Demographic Data of Cystic Fibrosis Patients in a Tertiary Care Center in Saudi Arabia. Asp J Pediatrics Child Health. 2020 June 27;2(2):44-51.

\section{Original Article}

elementary school level, and only $6.0 \%$ have a fulltime job, which makes them completely dependent on both parents for their care. Median survival improved from 8 years in 1984 to 22 years. More efforts need to be applied to different aspects of care to further improve median survival to parallel that of the European or North American data.

\section{Acknowledgment}

None

\section{Conflict of Interest}

All authors have read and approved the final version of the manuscript. The authors have no conflicts of interest to declare.

\section{References}

[1] Banjar H, Angyalosi G. The road for survival improvement of cystic fibrosis patients in Arab countries. Int J Pediatr Adolesc Med. 2015 Jun;2(2):4758. [PMID: 30805437]

[2] WHO Human Genetics Programme. The molecular genetic epidemiology of cystic fibrosis: report of a joint meeting of WHO/IECFTN/ICF(M)A/ECFS, Genoa, Italy, 19 June 2002. World Health Organization; 2004. Available from:

https://apps.who.int/iris/handle/10665/68702

[3] Pallin M. Cystic fibrosis vigilance in Arab countries: The role of genetic epidemiology. Respirology. 2019 Feb;24(2):93-94. [PMID: 30548951]

[4] Frossard PM, Lestringant G, Girodon E, Goossens M, Dawson KP. Determination of the prevalence of cystic fibrosis in the United Arab Emirates by genetic carrier screening. Clin Genet. 1999 Jun;55(6):496-97. [PMID: 10450871]

[5] Singh M, Rebordosa C, Bernholz J, Sharma N. Epidemiology and genetics of cystic fibrosis in Asia: In preparation for the next-generation treatments. Respirology. 2015 Nov;2O(8):1172-81. [PMID: 26437683]

[6] Nazer HM. Early diagnosis of cystic fibrosis in Jordanian children. J Trop Pediatr. 1992 Jun;38(3):11315. [PMID: 1507302]

[7] Al-Mahroos F. Cystic fibrosis in bahrain incidence, phenotype, and outcome. J Trop Pediatr. 1998 Feb;44(1):35-39. [PMID: 9538604]
[8] Farrell PM. The prevalence of cystic fibrosis in the European Union. J Cyst Fibros. 2008 Sep;7(5):450-53. [PMID: 18442953]

[9] Salvatore D, Buzzetti R, Baldo E, Furnari ML, Lucidi V, Manunza D, Marinelli I, Messore B, Neri AS, Raia V, Mastella G. An overview of international literature from cystic fibrosis registries. Part 4: update 2011. J Cyst Fibros. 2012 Dec;11(6):480-93. [PMID: 22884375]

[10] Mehta G, Macek M Jr, Mehta A; European Registry Working Group. Cystic fibrosis across Europe: EuroCareCF analysis of demographic data from 35 countries. J Cyst Fibros. 2010 Dec;9 Suppl 2:S5-S21. [PMID: 21041121]

[11] McCormick J, Mehta G, Olesen HV, Viviani L, Macek M Jr, Mehta A; European Registry Working Group. Comparative demographics of the European cystic fibrosis population: a cross-sectional database analysis. Lancet. 2010 Mar 20;375(9719):1007-13. [PMID: 20304245]

[12] Buzzetti R, Salvatore D, Baldo E, Forneris MP, Lucidi V, Manunza D, Marinelli I, Messore B, Neri AS, Raia V, Furnari ML, Mastella G. An overview of international literature from cystic fibrosis registries: 1. Mortality and survival studies in cystic fibrosis. J Cyst Fibros. 2009 Jul;8(4):229-37. [PMID: 19419909] [13] Barr HL, Britton J, Smyth AR, Fogarty AW. Association between socioeconomic status, sex, and age at death from cystic fibrosis in England and Wales (1959 to 2008): cross sectional study. Version 2. BMJ. 2011 Aug 23;343:d4662. [PMID: 21862532]

[14] Schechter MS, McColley SA, Silva S, Haselkorn T, Konstan MW, Wagener JS; Investigators and Coordinators of the Epidemiologic Study of Cystic Fibrosis; North American Scientific Advisory Group for ESCF. Association of socioeconomic status with the use of chronic therapies and healthcare utilization in children with cystic fibrosis. J Pediatr. 2009 Nov;155(5):634-39.e1-4. [PMID: 196o8199]

[15] Oates GR, Schechter MS. Socioeconomic status and health outcomes: cystic fibrosis as a model. Expert Rev Respir Med. 2016 Sep;10(9):967-77. [PMID: 27268142]

[16] Bell SC, Bye PT, Cooper PJ, Martin AJ, McKay KO, Robinson PJ, Ryan GF, Sims GC. Cystic fibrosis in Australia, 2009: results from a data registry. Med J Aust. 2011 Oct 3;195(7):396-400. [PMID: 21978347] 
Citation: Banjar H, Kadan H, Al-Abdaly D, Sheikh M, Al-Kaf S, Ghomraoui R, AIDoss A, Al-Eid M. Demographic Data of Cystic Fibrosis Patients in a Tertiary Care Center in Saudi Arabia. Asp J Pediatrics Child Health. 2020 June 27;2(2):44-51.

\section{Original Article}

[17] Watts KD, Seshadri R, Sullivan C, McColley SA. Increased prevalence of risk factors for morbidity and mortality in the US Hispanic CF population. Pediatr Pulmonol. 2009 Jun;44(6):594-601. [PMID: 19437506] [18] Stephenson A, Hux J, Tullis E, Austin PC, Corey M, Ray J. Socioeconomic status and risk of hospitalization among individuals with cystic fibrosis in Ontario, Canada. Pediatr Pulmonol. 2011 Apr;46(4):376-84. [PMID: 20967840]

[19] O'Connor GT, Quinton HB, Kneeland T, Kahn R, Lever T, Maddock J, Robichaud P, Detzer M, Swartz DR. Median household income and mortality rate in cystic fibrosis. Pediatrics. 2003 Apr;111(4 Pt 1):e333-39. [PMID: 12671148]

[20] Ong T, Schechter M, Yang J, Peng L, Emerson J, Gibson RL, Morgan W, Rosenfeld M; EPIC Study Group. Socioeconomic Status, Smoke Exposure, and Health Outcomes in Young Children With Cystic Fibrosis. Pediatrics. 2017 Feb;139(2):e20162730. [PMID: 28093464]

[21] Yan J, Cheng Y, Fine JP, Lai HJ. Uncovering symptom progression history from disease registry data with application to young cystic fibrosis patients. Biometrics. 2010 Jun;66(2):594-602. [PMID: 19522871]

[22] Quittner AL, Schechter MS, Rasouliyan L, Haselkorn T, Pasta DJ, Wagener JS. Impact of socioeconomic status, race, and ethnicity on quality of life in patients with cystic fibrosis in the United States.
Chest. 2010 Mar;137(3):642-50. [PMID: 19820076] [23] Goldbeck L, Besier T, Hinz A, Singer S, Quittner AL; TIDES Group. Prevalence of symptoms of anxiety and depression in German patients with cystic fibrosis. Chest. 2010 Oct;138(4):929-36. [PMID: 20472857]

[24] Banjar H, Mogarri I. Demographic and clinical data of cystic fibrosis (CF) patients in a tertiary care center in Saudi Arabia. Emirates Medical Journal. 1998 Dec;16(3):166-69.

[25] Banjar H. Overview of cystic fibrosis patients aged 1-12 years in a tertiary care center in Saudi Arabia. middle East Paediatr. 1999;4:44-50.

[26] Banjar H, Al-Mogarri I, Nizami I, Al-Haider S, AlMaghamsi T, Alkaf S, Al-Enazi A, Moghrabi N. Geographic distribution of cystic fibrosis transmembrane conductance regulator (CFTR) gene mutations in Saudi Arabia. International Journal of Pediatrics and Adolescent Medicine. 2019 Dec 10.

[27] Stephenson AL, Tom M, Berthiaume Y, Singer LG, Aaron SD, Whitmore GA, Stanojevic S. A contemporary survival analysis of individuals with cystic fibrosis: a cohort study. Eur Respir J. 2015 Mar;45(3):670-79. [PMID: 25395034]

[28] MacKenzie T, Gifford AH, Sabadosa KA, Quinton HB, Knapp EA, Goss CH, Marshall BC. Longevity of patients with cystic fibrosis in 2000 to 2010 and beyond: survival analysis of the Cystic Fibrosis Foundation patient registry. Ann Intern Med. 2014 Aug 19;161(4):233-41. [PMID: 25133359] 